\title{
Basic Japanese E-learning Application with Prototype Methodology
}

\author{
Najaemin F. Sianturi
}

Program Studi Pendidikan Ilmu Komputer, FPMIPA, Universitas Pendidikan Indonesia

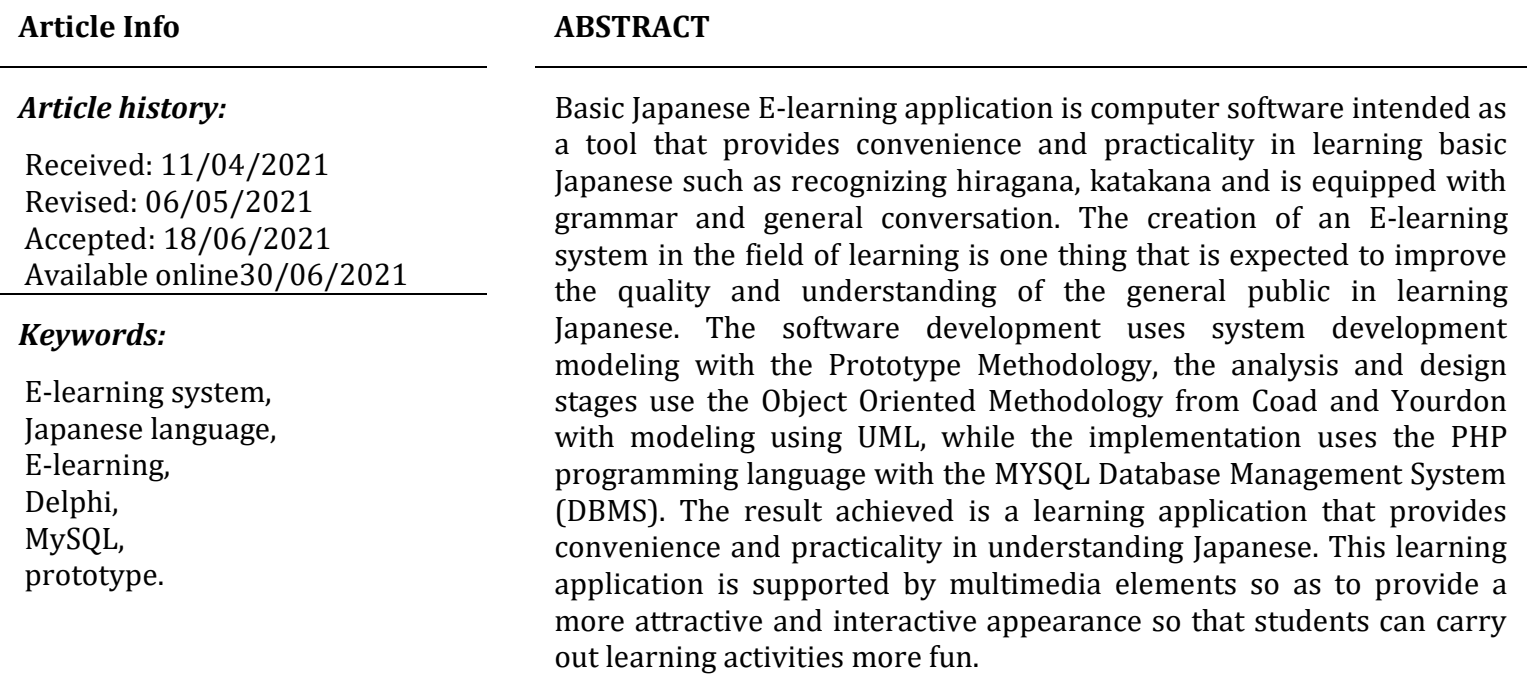

This is an open access article under theCC BY-NClicense.

\section{Corresponding Author:}

Najaemin F. Sianturi,

Program Studi Pendidikan Ilmu Komputer, FPMIPA, Universitas Pendidikan Indonesia

Email: najaemin09@gmail.com

\section{Introduction}

Language is one of the tools to communicate which is very important in the era of globalization (Murti, 2015) (Nasution, 2007). In this era, a person is required to be able to master more than one foreign language in order to improve human resources in the face of increasingly stringent competitiveness. Besides English which is an international language (Munadzdzofah, 2018) (Purhantara, 2010), Japanese has also become one of the foreign languages that need to be learned. This is due to the very rapid growth of the State of Japan in all fields, especially in the fields of technology and industry, for example, the number of products imported from Japan in the form of electronic equipment, vehicles, and even daily necessities (Ahmad, 2015) (Minah, n.d.).

There are many books that support learning Japanese that do not and provide convenience in learning Japanese directly because in reality the interest in reading books is still minimal. Besides that, there is no learning aid that suits the needs of what students want (Puspitasari, 2019) (Dini Hamidin, Andarsyah, \& Indonesia, n.d.).

With these problems, this topic was taken to write a thesis with the title "Basic Japanese Elearning Application with Prototype Methodology".

\section{Method}

The methodology that will be used in this research consists of the following steps:

a. Data collection technique 
In writing the final project required supporting data obtained by a relevant data collection method(Fitriyani, Sasono Wibowo, \& Kom, 2013). Data collection methods used to obtain data are as follows.

1). Observation

Observation is a direct observation of an object to be studied in a short time and aims to get an overview of the object of research. Observations were made to observe directly the effect of information technology on students' understanding of learning about the subjects given.

2). Interview

Interviews are a way to collect data by conducting interviews or direct Q\&A with teaching staff at SMP Negeri 1 Gunungtanjung, Tasikmalaya Regency. A detailed list of questions that the author asked can be seen in the attachment.

3). Literature review

In this method, the authors quote from several reading sources related to the problems studied, which can be in the form of theories or opinions from several reading books. It is intended to provide a solid theoretical foundation through books or literature available in libraries and the internet.

4). Documentation Methodology

That is a technique of collecting data by using archives or written manuscripts.

\section{Results and Discussion}

Self-directed learning is a course or program that gives individuals the opportunity to choose outcomes, design their own activities and carry out their activities according to their choice. This independent learning is student-centred (student-centred approach) where the learning process and experience is regulated and controlled by the students themselves. Students decide for themselves how, where, and when to learn about something that they consider important.

a. The proposed solutions to overcome the problems faced in the Japanese language learning process are:

1). The design of an e-learning application using a network-based computerized system and supported by multimedia.

2). The application made is only used as a tool in learning Japanese.

3). The material is given in full in a more attractive form to make it easier to understand the material

4). Designing an application that prioritizes ease of use of the application and adds visual and sound facilities, and is equipped with attractive facilities so that users get a clearer picture of the material being studied.

In accordance with the results of the interviews that have been conducted, it is hoped that the e-learning application created can meet all the needs needed by ordinary people to be able to better understand Japanese lessons.

b. SWOT analysis

1). System Strength (Stength)

Individually, Self-Learning has specific appeals, such as greater freedom to choose, flexibility, and benefiting from learning skills while actively undergoing Independent Learning while at the same time experiencing beneficial changes in learning attitudes and behavior.

2). System Weaknesses (Weaknesses)

This Independent Learning System has a weakness, namely the absence of interaction between other students and with teachers or instructors in the learning process. So it is feared that there will be misunderstandings in interpreting something they do not understand correctly.

3). System Opportunity (Opportunity) 
The presentation of the content of the material needed in the independent learning process can be packaged to be more attractive into a learning tool / media to provide convenience in the learning process so that students are expected to be able to understand the lesson quickly.

4). System Challenge (Threat)

With the opportunity mentioned above, there are several challenges that must be solved, namely how to make the content of the material to be studied more interesting, how long c. Interface Design it takes to design and the amount of money needed from design to implementation.

The interface design for this elearning application is as follows:

1). Homepage Display Design

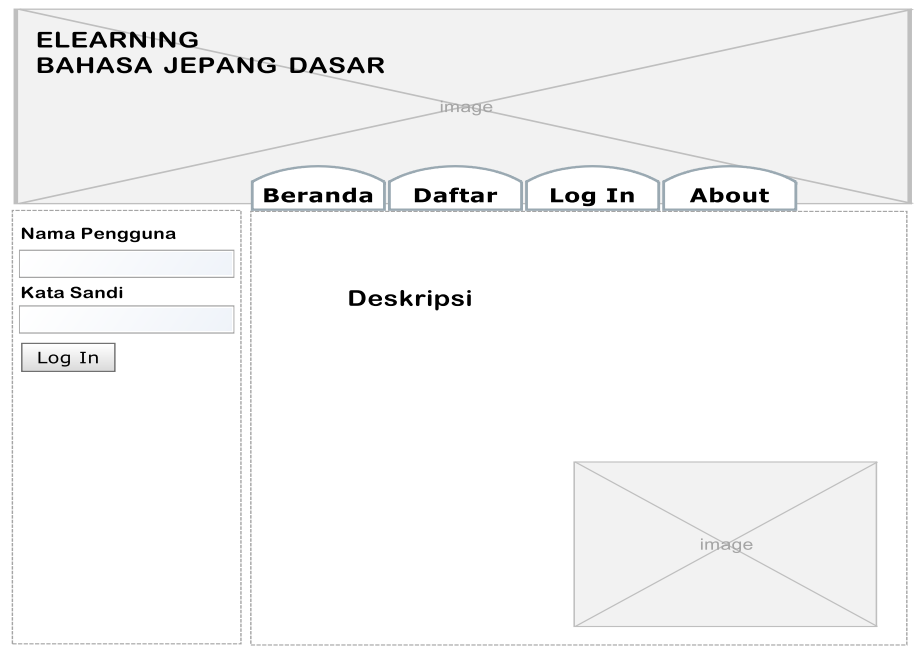

Figure 1. Home Page Display Design

2). List Page Display Design

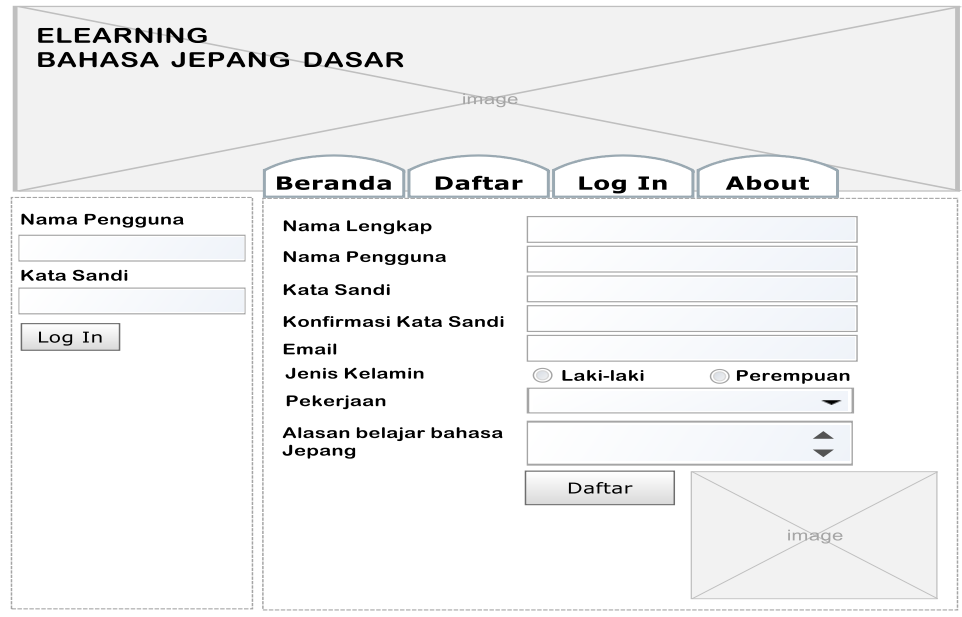

Figure 2. List Page Display Design

3). Material Page Display Design 


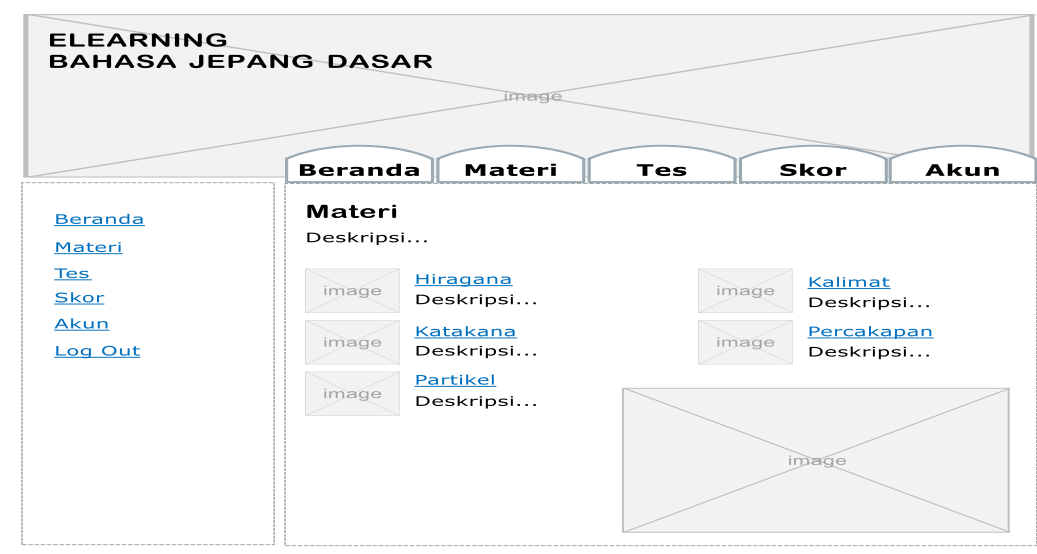

Figure 3. Material Page Display Design

4). Value/Score Page Display Design

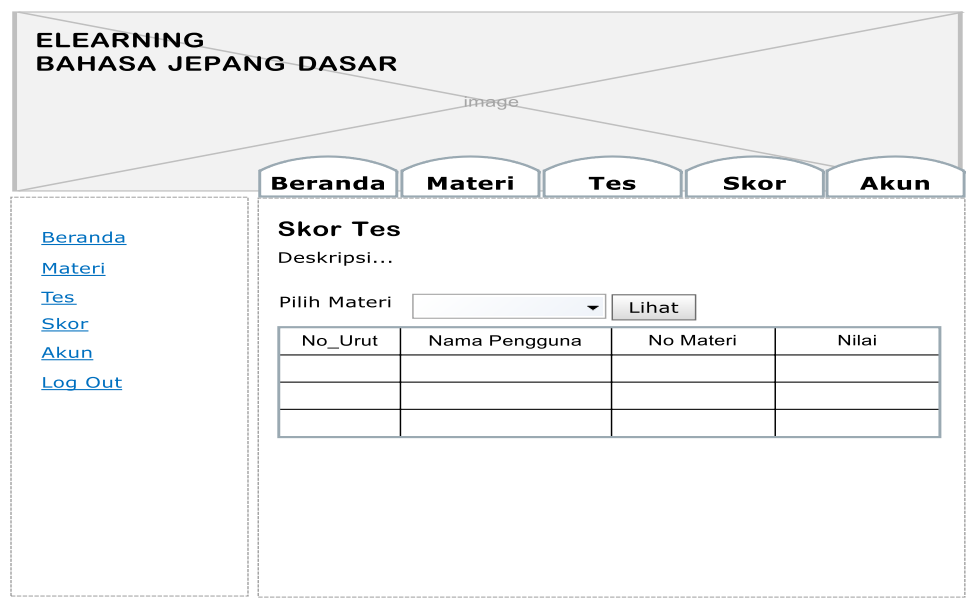

Figure 4. Value/Score Page Display Design

d. Elearning Application Implementation

This e-learning application uses several entities that are adapted to the use case and class diagrams written in the previous chapter. The implementation is as follows:

Table 1.

Implementation of Functions per Usecase of Elearning Applications

\begin{tabular}{|c|c|c|c|c|c|c|}
\hline No & Use Case & Boundary & Control & Entity & Address & Pages (*.php) \\
\hline 1 & list & Register Page & Add data & tbuser & $\begin{array}{l}\text { Menu, } \\
\text { Register }\end{array}$ & Signup.php \\
\hline 2 & Login & Login Page & Filter & tbuser & Menu, Login & Login.php \\
\hline 3 & $\begin{array}{l}\text { Choosing } \\
\text { Material }\end{array}$ & User home page & $\begin{array}{c}\text { Show } \\
\text { material } \\
\text { menu }\end{array}$ & tbmaterial & $\begin{array}{c}\text { Menu, } \\
\text { Material }\end{array}$ & Material.php \\
\hline 4 & $\begin{array}{c}\text { Edit User } \\
\text { Account } \\
\text { Data }\end{array}$ & $\begin{array}{l}\text { User account } \\
\text { edit page }\end{array}$ & $\begin{array}{c}\text { Update, clear } \\
\text { data }\end{array}$ & tbuser & $\begin{array}{c}\text { Menu, } \\
\text { Account, edit }\end{array}$ & Editaccount.php \\
\hline 5 & $\begin{array}{l}\text { Doing the } \\
\text { test }\end{array}$ & test page & Add data & $\begin{array}{l}\text { Tbuser, } \\
\text { tbmaterial, } \\
\text { tbquestion, } \\
\text { tbvalue }\end{array}$ & Menu, test & test.php \\
\hline 6 & View test & Test scores list & view data, & Tbuser, & Menu, value & score.php \\
\hline
\end{tabular}




\begin{tabular}{|c|c|c|c|c|c|c|}
\hline No & Use Case & Boundary & Control & Entity & Address & Pages (*.php) \\
\hline & scores & page & filter & $\begin{array}{l}\text { tbmaterial, } \\
\text { tbquestion, } \\
\text { tbvalue }\end{array}$ & list & \\
\hline \multirow{2}{*}{7} & Material & $\begin{array}{l}\text { Add material } \\
\text { data page }\end{array}$ & Add data & tbmaterial & $\begin{array}{c}\text { Menu, } \\
\text { Material }\end{array}$ & $\underset{\mathrm{p}}{\text { input_material.ph }}$ \\
\hline & $\mathrm{n}$ & $\begin{array}{l}\text { Material data } \\
\text { edit page }\end{array}$ & $\begin{array}{c}\text { Update, clear } \\
\text { data }\end{array}$ & tbmaterial & $\begin{array}{l}\text { Menu, } \\
\text { materials }\end{array}$ & edit_material.php \\
\hline \multirow[t]{2}{*}{8} & $\begin{array}{c}\text { Manipulatio } \\
n \text { of test }\end{array}$ & $\begin{array}{c}\text { Add test } \\
\text { question data } \\
\text { page }\end{array}$ & Add data & tb question & $\begin{array}{l}\text { Menu, Test } \\
\text { Questions }\end{array}$ & input_test.php \\
\hline & questions & $\begin{array}{l}\text { Test question } \\
\text { data edit page }\end{array}$ & $\begin{array}{c}\text { Update, clear } \\
\text { data }\end{array}$ & tb question & $\begin{array}{l}\text { Menu, Test } \\
\text { Questions }\end{array}$ & edit_test.php \\
\hline
\end{tabular}

e. Black Box Test

Black Box Testing is an application test with an approach that assumes a software or program as a black box. This approach only evaluates the program from the output or the final output issued by the application. Black Box testing on this e-learning application is done by taking samples from the new user registration process. The following are the results of the Black Box testing of the process new user run. The following are the results of the Black Box testing of the process

Table 2.

Implementation of Functions per Usecase of Elearning Applications

\begin{tabular}{|c|c|c|c|c|}
\hline & \multirow{2}{*}{$\begin{array}{l}\text { Test Scenario } \\
\text { Input user data (if the data } \\
\text { is not complete) }\end{array}$} & \multirow{2}{*}{$\begin{array}{l}\text { Expected results } \\
\text { The message "Incomplete data" } \\
\text { appears. }\end{array}$} & \multirow{2}{*}{$\begin{array}{l}\text { Test results } \\
\text { In } \\
\text { accordance }\end{array}$} \\
\hline & & & & \\
\hline & \multirow{2}{*}{$\begin{array}{l}\text { Requirements } \\
\text { User Data } \\
\text { Input }\end{array}$} & $\begin{array}{l}\text { Input item data (if the user } \\
\text { name or email is already } \\
\text { registered) }\end{array}$ & $\begin{array}{l}\text { The message "User name or } \\
\text { email has been registered" } \\
\text { appears. }\end{array}$ & $\begin{array}{l}\text { In } \\
\text { accordance }\end{array}$ \\
\hline & & Click the Register button & $\begin{array}{l}\text { The data will be stored in the } \\
\text { database in the user table. }\end{array}$ & $\begin{array}{l}\text { In } \\
\text { accordance }\end{array}$ \\
\hline
\end{tabular}

\section{Conclusion}

The conclusion that can be drawn from the results of the implementation and testing of e-learning applications is that this teaching device conveys learning material using a more attractive appearance when compared to learning methods based on books only. This Elearning application is only as a learning tool for people who do independent learning in learning Japanese. Based on the results of white box and black box testing, the developed application is in accordance with what has been designed.

\section{Reference}

Ahmad, J. (2015). Kebijakan Industri Malaysia: Kebijakan Industri Mahatir 1988-1985. Islamika: Jurnal Ilmu-Ilmu Keislaman, 15(1), 100-115.

Dini Hamidin, W. R., Andarsyah, R., \& Indonesia, P. P. (n.d.). PENINGKATAN KUALITAS SEKOLAH DENGAN PELATIHAN TIK DAN BAHASA DAN MINAT BACA SISWA DI SD JUARA BANDUNG DAN CIMAHI.

Fitriyani, I., Sasono Wibowo, S. E., \& Kom, M. (2013). Sistem Informasi Penggajian Karyawan Pada PT. Indotirta Jaya Abadi (Aguaria) Semarang. Jurusan Sistem Informasi Universitas Dian Nuswantoro Semarang, 1-8.

Minah, T. (n.d.). Politik Industrialisasi Di Korea Selatan (Studi Atas Peran Negara Dalam Pengembangan Teknologi Dan Industri Periode 1990-2002). Fisip UIN Jakarta.

Munadzdzofah, O. (2018). Pentingnya Bahasa Inggris, China, dan Jepang Sebagai bahasa Komunikasi Bisnis di era Globalisasi. VOCATIO: Jurnal Ilmiah Ilmu Administrasi Dan Sekretari, 1(2), 58-73.

Murti, S. (2015). Eksistensi penggunaan bahasa indonesia di era globalisasi.

Nasution, Z. (2007). Bahasa sebagai alat komunikasi politik dalam rangka mempertahankan kekuasaan. Sodality: Jurnal Sosiologi Pedesaan, 1(3).

Purhantara, W. (2010). Kepemimpinan Bisnis Indonesia di Era Pasar Bebas. Jurnal Ekonomi Dan Pendidikan, 7(1). 
Puspitasari, A. D. (2019). Penerapan Media Pembelajaran Fisika Menggunakan Modul Cetak dan Modul Elektronik pada Siswa SMA. JPF (Jurnal Pendidikan Fisika) Universitas Islam Negeri Alauddin Makassar, 7(1), 17-25. 